\title{
Optimization of production and animal transit in an integrated crop-livestock system with no-tillage
}

\author{
Vinicius Teixeira do Nascimento ${ }^{1}$, Angel Ramon Sanchez Delgado ${ }^{1,2}$ (D) \& Sergio \\ Drumond Ventura ${ }^{2}$
}

(1) Universidade Federal Rural do Rio de Janeiro, Instituto de Ciências Exatas, Departamento de Matemática, Programa de Mestrado em Modelagem Matemática e Computacional, Rodovia BR 465, Km 07, Zona Rural, Seropédica 23897-000, Rio de Janeiro, Brazil. E-mail: vinicius.tn@gmail.com

(2) Universidade Federal Rural do Rio de Janeiro, Instituto de Ciências Exatas, Departamento de Matemática, Rodovia BR 465, Km 07, Zona Rural, Seropédica 23897-000, Rio de Janeiro, Brazil. E-mail: asanchez@ufrrj.br, ventura@ufrrj.br
Nascimento V.T., Delgado A.R.S. \& Ventura S.D. (2019) Mixed integer programming for the numerical simulation of an integrated crop-livestock system with no-tillage. Pesquisa e Ensino em Ciências Exatas e da Natureza, 3(1): 07-17. http://dx.doi.org/10.29215/pecen.v3i1.1145

Academic editor: Eudes Leite de Lima. Received: 26 December 2018. Accepted: 08 March 2019. Published: 27 May 2019.

Otimização da produção e trânsito animal em um sistema integrado lavoura-pecuária com plantio direto

Resumo: Atualmente os sistemas integrados de produção lavoura-pecuária têm se apresentado como uma alternativa viável e sustentável em termos econômicos, sociais e ambientais. Este trabalho desenvolve e implementa computacionalmente um modelo de programação inteira mista (MIXP) que representa ou simula numericamente as condições operacionais ótimas de um sistema integrado lavoura-pecuária com plantio direto (SILPE-PD), incluindo trânsito animal. Para a implementação computacional do modelo, foram impostas condições sobre a adequação do ganho do peso vivo de cada animal do rebanho considerado, em cada período e área do SILPE-PD (confinamento, pastagem e cultivo anual de culturas agrícolas), bem como rendimento líquido marginal de cada cultura e os custos por unidade de alimento considerados. Com dados gerados aleatoriamente verificou-se a validade do modelo matemático desenvolvido. Cada MIXP foi resolvido utilizando o solver INTLINPROG no software MATLAB. Assim, após a implementação computacional, verificou-se que o programa atende a todas as restrições impostas, maximiza o ganho de peso de cada animal, proporciona a melhor seleção de culturas anuais e minimiza os custos de alimentação na área de confinamento.

Palavras chave: Confinamento animal, compactação do solo, pastagem, trânsito animal.

\begin{abstract}
Nowadays integrated crop-livestock production systems have been presented as a viable and sustainable alternative in economic, social and environmental terms. This work develops and implements a mixed integer programming model (MIXP) that represents or simulates numerically the optimum operational conditions of an integrated crop-livestock system with no-tillage (iCLS-NT), including animal transit. For the computational implementation of the model, data on the fitness of the live weight gain of each animal of the herd considered, in each period and area of the (iCLS-NT), (confinement, pasture and annual crop), as well as marginal net income of each crop and the costs per unit of food considered. In order to test the validity of the developed mathematical model, data were randomly generated. To solve each MIXP, we used the solver INTLINPROG in the software MATLAB. Thus, after the computational implementation, it was verified that the program meets all restrictions imposed, maximizes the weight gain of each animal, provides the best selection of annual crops and minimizes feeding costs in the confinement area.
\end{abstract}

Key words: Animal confinement, soil compaction, pasture, animal transit. 


\section{Introduction}

Fundamentally, conventional agricultural production is based on monoculture. Monoculture is the cultivation of a single agricultural species in a particular area or region, occurring more intensely on large farms. In Brazil, this is a well-known model, because since this country began its development as an agrarian country, it concentrated its efforts in specific cultures, as was the case of sugarcane, coffee and, currently, soy. These large-scale productions are generally intended for the market, especially for the external market and for animal consumption in the form of feed. It is known that the specialization of monoculture as a whole, is extremely harmful to the soil, causing significant environmental imbalance, due to the wear and nutritional impoverishment caused by the continuous production of the same plant and the consequent contamination, generated by the indiscriminate use of fertilizers, with the aim of maintaining or recovering the productivity of the land, and of agrochemicals, which are essential to combat the pests that arise due to the uniformization of crops.

Also, among the negative factors, we can also mention soil compaction, deforestation, excessive consumption of water and energy in irrigated projects and the process of sedimentation of rivers and springs. The system still compromises biodiversity, increasing the insect population and decreasing the number of wild animals. When removing a diverse vegetable area, the animals also face problems, since they have difficulty in feeding, finding shelters and, consequently, reproducing. There are cases where the surviving animals have sought out urban areas to house themselves, making them easy prey.

The impacts of monoculture also affect the economy and society. This is because the system is at risk with diseases or pests, besides the fall in the price of the product in the market, putting the regional productive chain in danger. In this sense, there is a greater incidence of rural populations exodus, since in the monoculture there is a use reduction of the labor force. There are estimations showing that on farms that grow products in these systems there are only 350.000 salaried workers. A small property would employ the double that number. In this way, environmental and social impacts make the process unsustainable, since it degrades all aspects considered good for development.

Currently, agricultural and environmental sustainability are at risk due to the necessary acceleration of global food production in the next 20 years (FAO). With the continuous growth of the world population and food demand, as well as the reduction of areas for the development of agricultural practices (justified by climatic problems), the world urgently seeks techniques that control both issues. In Brazil, estimations show that by 2050, food production should double, and as a consequence, we will have a pressure on production systems (Ferreira et al. 2010). With the increase of production, we expect an intensification on the opening of new agricultural areas (Pires et al. 2010). Now, it is clear that the intensification of production systems is not a simple task to be undertaken because of the high percentage of degraded soils existing at national level.

On the other hand, considering that the profitability of small, medium and even large agricultural producers is increasingly constrained (financing, high interest rates, often unfavorable weather conditions, public policies without major impacts, high mechanization costs, shortages and price increasing of resources related to production, water restrictions, etc.), it is necessary to look for alternatives of agricultural production such as the so-called "integrated farming-livestock systems" that make the agricultural practices in these properties economically, socially, and environmentally feasible.

An integrated crop-livestock system (iCLS) consists of the exploration of agricultural and livestock activities, in an integrated way, in rotation or succession, in the same area and at different times, in this way increasing the efficiency in the use of natural resources, with less impact on the environment, since degradation processes are controlled through conservation practices.

Among the $i C L S \mathrm{~s}$, the crop-livestock integration system under no-tillage has been one of the most sustainable systems, since it maximizes the rational use of the soil, permits nutrient cycling, and improves soil biology and soil-climatic conditions (Oliveira 2002). This technique is 
applied to the plantation after harvesting, using what is left over to cover the soil and developing pasture area for livestock during this period, taking care that there is no compaction of the soil by animal trampling.

The no-tillage system generates benefits such as low machining in the agricultural production process, maintenance of soil properties without need of resting or treatments against infertility, and better utilization of the area, generating greater gains with lower costs. However, many producers are reluctant to adopt this system because of the effect of animal trampling on soil physical attributes, especially those related to compaction (Sá \& Santos Junior 2005).

According to Carvalho et al. (2004), the system of no-tillage for grains on winter pasture, when well-managed, ensures a good soil conservation and guarantees the stability of the system. We also expect to improve the chemical, physical and biological properties of the soil and reduce the occurrence of pests, diseases and weeds (Lorenzi 2000).

In this work, we developed and implemented a mixed integer programming model (MIXP) that numerically represents or simulates the optimum operating conditions of an integrated crop-livestock system with no-tillage (iCLS-NT), including transit or animal circulation. MIXP maximizes live weight gain for each animal, provides the best selection of annual crops, and minimizes feeding costs in the feedlot area.

\section{Material and Methods}

We worked with several randomly-generated agricultural scenarios, consisting of five annual crops, a maximum of three animals per iCLS-NT area, 550 ha as maximum total area, $550 \mathrm{~m}^{3}$ as maximum value of water volume, five types of food for feeding composition, five nutrients required per unit in the composition of a given food and $1 \mathrm{~kg}$ as the maximum value of the lower limit of the quantity of a particular type of food.

The parameters: animal weight, crop prices, average crop yield, average of average crops cost, marginal net revenue, volume of water required for each crop, cost per unit of each feed, minimum nutrient value required in the diet, live weight for animal abatement and animal weight gain, were randomly generated in MATLAB.

Figure 1 shows the graphical representation of a no-tillage iCLS system called iCLS-NT. It is an agricultural structure composed of three areas of activity: annual crop, pasture and animal confinement (composition of food, feed and/or pasture, dry matter, crude protein, etc.). The arrows indicate the possible transit or animal movement allowed in the system.

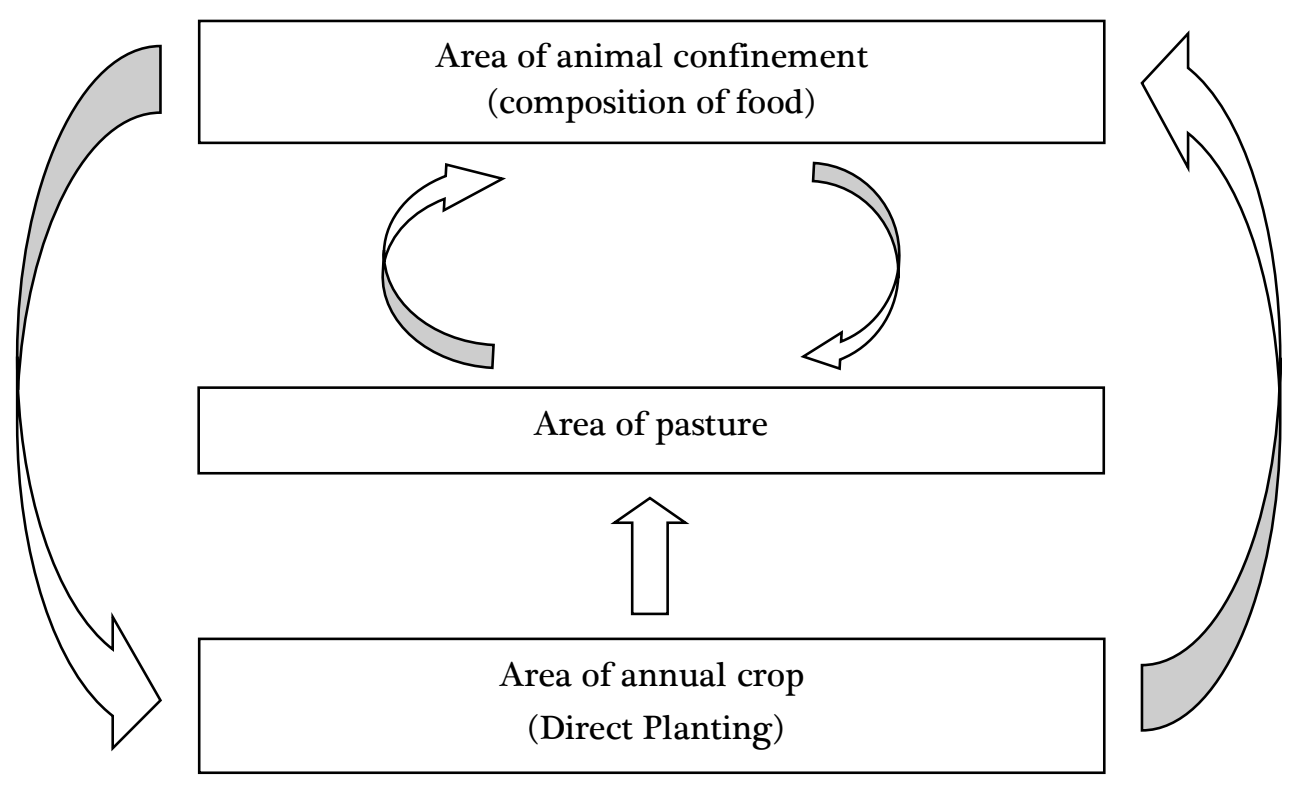

Figure 1. Graphical representation of iCLS-NT (iCLS-No-Tillage Planting) and transit or animal circulation. 
The area of animal confinement is where a certain number of animals can be fed with various diets that make them show all their genetic characteristics, especially the gain of live weight. The diets used in confinement are generally rich in concentrates (corn, soybean meal, sorghum), since these foods have more nutrients than the voluminous ones (elephant grass, tifton, tanzania, etc.).

Considering that confinement is costly, if we compare with the other two areas, this area should be used as a tool for livestock and not as a total production system, that is, the animal is taken to this area only when it is indispensable and for the shortest possible period. For this area, two types of animals are destined, animals that reach a certain weight (usually around $350 \mathrm{~kg}$ ) with the objective of depositing fat in the carcass, being confined for an average time of 100 days and very underweight animals, where it is not possible to determine a certain weight since it is also necessary to take into account the animal age.

The permanent pasture area is the central area of animal flow (or transit) in the iCLSNT. In this area, there is no cost constraint on keeping the animal (as opposed to the confinement area). We are also assuming that in this area there may be no limitations on the number of animals allowed (as opposed to the annual crop area). The pastures considered may be natural or native. The choice varies, taking into account the creation, soil and climate of the region, as well as the property conditions. In the natural pastures we have the original vegetation composed by various species of herbaceous, grasses, non-grasses and shrub. On the other hand, in the native pastures we have spontaneous vegetation composed by the type of plants used as fodder and that grows after the destruction of the original vegetation.

The annual crop area of the iCLS-NT is composed of one or several subareas or areas where are carried out agricultural activities (production of grains together with soil recovering species) and livestock in rotation. Regarding the traffic or animal circulation, key to the success of iCLS-NT, certain rules must be respected that allow a harmony between crop and livestock. Among the rules are the off-season to release the animals, respecting the maximum number of animals allowed and trying to reduce the compaction of the soil by animal trampling, and the high costs involved in keeping the animal confined. In this way, the animal will be kept as short as possible in the confinement area, that is, in the final stage of fattening for the slaughter of the animal, only animals that present live weight much under the weight for its age can remain confined. Otherwise, the animals should be moved to the pasture or crop area in the off-season. We are assuming that there is a consortium between grain crops and forage crops.

Note in Figure 1 that animals in the grazing area can be rotated with the animal containment area each time it is needed. Also, from the crop area, the current herd (total or partial) can be moved to the pasture area or again to the confinement area, depending on the live weight of the animal. In the off-season, crop residues can be used to feed animals. This procedure, besides feeding the animals, also contributes to the conservation of the soil through the fertilizer. Regarding the controversial soil compaction, it is necessary to limit the number of animals in each area of operation of the system.

In the following, we will assume that the iCLS-NT is developed in a perimeter in period of off-season of the annual crop. At the same time, we can assume that we have a non-native pasture (elephant paradise, for example), ready to supply the food composition area, and also allow the animal circulation for a certain period before the new harvest. Also, the live weight of each animal of the herd considered is known.

The criteria to be used for the passage of an animal from one area to another will depend on the live weight of the animal. In this way, it is possible to imagine that we have a set of routes or feasible paths between the areas of confinement, pasture and annual crop, among which we want to choose the optimal route of circulation that each animal of the herd will have to carry out during the implementation of the system. Also, it is important to determine the crops and months of planting for crop development that provide the maximum net income with water and land constraints (Delgado et al. 2016), as well as the feed optimization of confined animals. The mathematical modeling of the three previous considerations will be done through mixed integer programming (MIXP). 
Below we present the construction of the mathematical model that represents the basic activities or operations of the iCLS-NT, such as optimum herd circulation, optimum crop selection for crop development and minimization of feed composition costs. Then, it follows the indexes, parameters, variables, constraints and objective of the MIXP model associated with the activities of the iCLS-NT.

\section{Indexes}

$l=1,2, \ldots . m$; where $m$ represents the number of crops considered.

$h=1, \ldots, 12$; months of the year.

$r=1,2 \ldots, p$; type of food in a food composition (grass, ration, corn without cobs, dry wash, combinations of the above, etc.).

$s=1,2, \ldots, d$; nutrient required per unit in the composition of a given food.

\section{Parameters}

$\theta_{i j h}-$ Weight for keeping animal $i$ in area $j$ in month $h(\mathrm{R} \$)$ (animal grazing, feeding, physical structure, equipment, etc.).

$N_{j h}$ - Maximum number of animals allowed in area $j$ in month $h$.

$p_{l h}$ - Price of crop $l$ in month $h\left(R \$ k g^{-1}\right)$.

$\gamma_{l}$ - Average productivity of crop $\left(k g h a^{-1}\right)$.

$c_{l}$ - Average of the average costs of crop $l$ including the water costs for irrigation $\left(R \$ h a^{-1}\right)$.

$R_{l h}=p_{l h} \gamma_{l}-c_{l}-$ Net marginal revenue $\left(R \$ h a^{-1}\right)$.

$v_{l h}$ - Volum of water required for crop $l$ in month $\left(m^{3} h a^{-1}\right)$.

$V T_{h}$ - Total water volume available in month $h\left(\mathrm{~m}^{3}\right)$.

$A T_{h}$ - Total irrigated area in month $h(h a)$.

$\rho_{r}$ - Cost per unit of feed $\left(R \$ \mathrm{~kg}^{-1}\right)$.

$\delta_{r s}-$ Percentage of nutrient $s$ in feed $r$.

$\sigma_{s}-$ Minimum value of nutrient $s$ required in the diet $(\mathrm{kg})$.

$P V_{i j}$ - Live weight of animal $i$, in area $j(\mathrm{~kg})$.

$P V A_{i j}$ - Live weight for the slaughter of animal $i$, in area $j(\mathrm{~kg})$.

$g_{i j h}$ - Weight gained by animal $i$ in area $j$ in month $h(\mathrm{~kg})$.

$z_{\min }-$ Total minimum amount of feed $(\mathrm{kg})$.

For each area $j$, let $S_{j}=\left\{i: P V_{i j}<P V A_{i j}\right\}$ and $\bar{S}_{J}=\left\{i: P V_{i j}<<P V A_{i j}\right\}$. Both sets indicate respectively the animals with insufficient and exceedingly low live weight for the for the slaughter. 


\section{Variables}
$y_{i j h}=1$
If animal $i$ is in the area $j$ in month $h$
$=0$
Otherwise.

$x_{l h}-$ Area cultivated by annual crop $l$ in month $h(h a)$.

$z_{r}-$ Amount of feed type $(\mathrm{kg})$.

\section{Constraints}

i) For each month $h$, the number of animals $i$ that may remain in area $j$, cannot exceed the amount of $N_{j h}$ animals.

$$
\sum_{i=1}^{n} y_{i j h} \leq N_{j h}, j=1,2,3, \quad h=1,2, \ldots .12 .
$$

ii) If in month $h$, animal $i$ is in the pasture area $(j=1)$ with insufficient live weight $\left(i \in S_{1}\right)$ for its slaughter, then animal $i$ must remain in the area for more one month.

$$
y_{i 1 h} \leq y_{i 1 h+1}, \quad h=1,2, \ldots, 11, \quad i \in S_{1}=\left\{i: P V_{i 1}<P V A_{i 1}\right\} .
$$

iii) If in month $h$, animal $i$ is in the crop area $(j=2)$ with live weight exceedingly low $\left(i \in \overline{S_{2}}\right)$ for its slaughter, then animal $i$ must be taken to the confinement area.

$$
y_{i 2 h} \leq y_{i 3 h}, \quad h=1,2, \ldots, 12, \quad i \in \overline{S_{2}}=\left\{i: P V_{i 2}<<P V A_{i 2}\right\}
$$

iv) If in month $h$, animal $i$ is in the pasture area $(j=1)$ with live weight exceedingly low $\left(i \in \overline{S_{1}}\right)$ for its slaughter, then animal $i$ must be taken to the confinement area.

$$
y_{i 1 h} \leq y_{i 3 h}, \quad h=1,2, \ldots, 12, \quad i \in \overline{S_{1}}=\left\{i: P V_{i 1}<<P V A_{i 1}\right\} .
$$

v) Constraints of planted areas regarding the total allowed area per month.

$$
\sum_{l=1}^{m} x_{l h} \leq A T_{h}, h=1,2, \ldots, 12
$$

vi) Constraints of water volumes required for crop development regarding the total available volume per month.

$$
\sum_{l=1}^{m} v_{l h} x_{l h} \leq V T_{h}, \quad h=1,2, \ldots, 12 .
$$




\section{Operational optimization of an integrated waste-livestock system}

vii) Constraints of food compositions in the confinement area.

$$
\sum_{r=1}^{p} \delta_{r s} z_{r} \geq \sigma_{s}, s=1,2, \ldots, d .
$$

viii) Each animal $i$ must be in one and only one area $j$ in month $h$.

$$
\sum_{j=1}^{3} y_{i j h}=1, \quad h=1,2, \ldots, 12, \quad i=1, \ldots, n
$$

ix) If animal $i$ is in the pasture area $(j=1)$ in month $h$, then it cannot be in the annual crop area $(j=2)$ in the next month $(h+1)$.

$$
y_{i 1 h}+y_{i 2 h+1} \leq 1, \quad h=1,2, \ldots, 11, \quad i=1, \ldots, n \text {. }
$$

x) The amount of feed type $r\left(z_{r}\right)$ must be greater than or equal to the minimum amount of food $(k g)$.

$$
\sum_{r=1}^{p} z_{r} \geq z_{\min }
$$

Following is the MIXP to represent the activities, operational conditions and objectives of the iCLS-NT.

Maximize

$$
\sum_{l=1}^{m} \sum_{h=1}^{12} R_{l h} x_{l h}+\sum_{i=1}^{n} \sum_{j=1}^{3} \sum_{h=1}^{12} g_{i j h} y_{i j h}-\sum_{i=1}^{n} \sum_{j=1}^{3} \sum_{h=1}^{12} \theta_{i j h} y_{i j h}-\sum_{r=1}^{p} \rho_{r} z_{r}
$$

Subject to:

$$
\begin{array}{lll}
\sum_{i=1}^{n} y_{i j h} \leq N_{j h}, & j=1,2,3, & h=1,2, \ldots, 12 \\
y_{i 1 h} \leq y_{i 1 h+1}, & h=1,2, \ldots, 11, & i \in S_{1}=\left\{i: P V_{i 1}<P V A_{i 1}\right\} \\
y_{i 2 h} \leq y_{i 3 h}, & h=1,2, \ldots, 12, & i \in \overline{S_{2}}=\left\{i: P V_{i 2}<<P V A_{i 2}\right\} \\
y_{i 1 h} \leq y_{i 3 h}, & h=1,2, \ldots, 12, & i \in \overline{S_{1}}=\left\{i: P V_{i 1}<<P V A_{i 1}\right\} \\
\sum_{l=1}^{m} x_{l h} \leq A T_{h}, & h=1,2, \ldots, 12 & \\
\sum_{l=1}^{m} v_{l h} x_{l h} \leq V T_{h}, & h=1,2, \ldots, 12 \\
\sum_{r=1}^{p} \delta_{r s} z_{r} \geq \sigma_{s}, & s=1,2, \ldots, d & \\
\sum_{j=1}^{3} y_{i j h}=1, & h=1,2, \ldots, 12, & i=1, \ldots, n \\
y_{i 1 h}+y_{i 2 h+1} \leq 1, & h=1,2, \ldots, 11, & i=1, \ldots, n \\
\sum_{r=1}^{p} z_{r} \geq z_{\text {min }} & & \\
y_{i j h} \in\{0,1\} \text { and } x_{l h}, & z_{r} \geq 0 .
\end{array}
$$


In Linear Programming, there are theoretically proven necessary and sufficient conditions of optimization that can be used to efficiently test whether a given feasible solution is an optimal solution or not. These conditions have been used to develop algebraic methods such as simplex and other methods for solving Linear Programming problems. In Integer Programming and Mixed Integer Programming, there are no optimization conditions known to test whether a given feasible solution is optimal except by explicitly or implicitly comparing this solution with each of the feasible solutions to the problem. This is the reason why these are solved by means of enumeration methods that search for an optimal solution in the set of feasible solutions, as in our case. With the computational implementation we could verify that the program satisfies all constraints imposed, maximizes the weight gain of each animal, provides the best selection of annual crops and minimizes the feeding costs in the confinement area.

\section{Results and Discussion}

Table 1 shows how many hectares should be cultivated per crop during each month of the year under consideration.

Table 1. Area to be cultivated by each of the five crops during each month of the year (ha).

\begin{tabular}{cccccc}
\hline & Crop 1 & Crop 2 & Crop 3 & Crop 4 & Crop 5 \\
\hline Month 1 & 0 & 0.7003 & 0 & 0 & 0 \\
Month 2 & 0 & 0 & 42.008 & 0 & 0 \\
Month 3 & 0 & 0 & 419.897 & 0 & 0 \\
Month 4 & 0 & 141.266 & 0 & 0 & 0 \\
Month 5 & 33.464 & 0 & 0 & 0 & 0 \\
Month 6 & 24.679 & 0 & 0 & 0 & 0 \\
Month 7 & 0 & 0 & 55.683 & 0 & 0 \\
Month 8 & 0 & 0 & 132.132 & 0 & 0 \\
Month 9 & 0 & 28.596 & 0 & 0 & 0 \\
Month 10 & 0 & 0 & 0 & 0 & 15.122 \\
Month 11 & 0 & 0 & 0 & 0 & 14.817 \\
Month 12 & 0 & 0 & 25.542 & 0 & 0 \\
\hline
\end{tabular}

Note that Table 1 nodes inform that it would be advisable to plant crop 1 only in May (33.464 ha) and in June (24.679 ha), crop 2 begins in January with 0.7003 ha, 141.266 ha in April and 28.596 ha in September, the crop is the most recommended crop to be cultivated in February (42.008 ha), March (419.897 ha), July (55.683 ha), August (132.132 ha) and December (25.542 ha). In this scenario it is not advisable to cultivate crop 4, and crop 5 only in October (15.122 ha) and November (14.817 ha). The restrictions of planted areas regarding the total allowable area per month and the volumes of water required for crop development regarding the total available volume per month are satisfactory. Table 2 represents the transit or animal circulation that is key to iCLS-NT.

Table 2 shows in which area of the iCLS-NT each animal is found during the respective months of the year. It says that animal 1 is in the annual crop area in the first month of the year, but should remain in the animal confinement area in the months 2, 3, 4, 5 and 6 of the year. In month 8, it must return to the animal confinement area and stay in the months 9, 10, 11 and 12 in the annual crop area. Animal 2 remains in the annual crop area during the first two months of the year, while in the other months in the pasture area.

Note that animal 3 is the animal with the highest circulation between the respective areas of the iCLS-NT. It remains in the confinement area during the first two months of the year, in the third and fourth month in the annual crop area, returns in the fifth month confinement, in the sixth in the annual crop, in the months 7 and 8 again return to the confinement and in the following months $9,10,11$ and 12, there is an alternation of permanence between the annual and confinement fields. Two values of minimum sum for animal feed $z_{r}$ 
were run, which did not interfere in the results of the permanent crop or in the animal traffic, remembering that the same random data were used. In Table 3, the two solutions are shown.

In the second line of Table 3, we observe something interesting, optimization increases the quantity in the less expensive types and the more expensive ones simply meets the minimum required in the animal diet. Economically, with the composition of a minimum sum of 10, an optimum objective value of $R \$ 24.069 .305 .00$ was obtained. This makes sense since no data is altered since the minimum amount of ration is already greater than $10 \mathrm{~kg}$. Now when the feed sum increases to 100 , the optimal target value drops to $\mathrm{R} \$ 17.053 .623 .00$. This is due to increased spending on the most costly part of the system, that is, the animal confinement.

Table 2. Transit or animal circulation in each area of the iCLS-NT and month of the year, respectively.

\begin{tabular}{cccc}
\hline & Pasture & Annual Crop & Confinement \\
\hline Month 1 & & $\begin{array}{c}\text { Animal 1 } \\
\text { Animal 2 }\end{array}$ & Animal 3 \\
\hline Month 2 & & Animal 2 & Animal 1 \\
& & Animal 3 \\
\hline Month 3 & Animal 2 & Animal 3 & Animal 1 \\
\hline Month 4 & Animal 2 & Animal 3 & Animal 1 \\
\hline Month 5 & Animal 2 & Animal 1 \\
\hline Month 6 & Animal 2 & Animal 3 \\
\hline Month 7 & Animal 2 & Animal 1 & Animal 1 \\
\hline Month 8 & Animal 2 & & Animal 3 \\
\hline Month 9 & Animal 2 & Animal 1 3 \\
\hline Month 10 & Animal 2 & Animal 3 & \\
\hline Month 11 & \multirow{2}{*}{ Animal 2 } & Animal 1 & Animal 3 \\
\hline Month 12 & Animal 2 & Animal 1 & \\
\hline
\end{tabular}

Table 3. Quantity of food type $\mathrm{r}(\mathrm{kg})$ for each minimum sum considered.

\begin{tabular}{cccccc}
\hline $\begin{array}{c}\text { Minimum } \\
\text { Summation }\end{array}$ & Type 1 & Type 2 & Type 3 & Type 4 & Type 5 \\
\hline 10 & 0.7306 & 5.6012 & 0.8332 & 0.3983 & 16.6107 \\
100 & 0.7306 & 0.6465 & 0.8332 & 0.3983 & 97.3915 \\
\hline
\end{tabular}

It is important to inform that during the development of this work we did not find in the literature a mathematical modeling (using mixed integer programming) that simulated the operability of an integrated iCLS-NT farming system, and therefore, it was not possible to confront the results obtained.

A further round was also carried out with the following values: 5 cultures, 5 animals, 4 as maximum number of animals per area, 1.250 ha as maximum value of total area, $1.250 \mathrm{~m}^{3}$ as maximum value of water volume, 5 types of food in one nutritional composition, 5 nutrients required per unit in the composition of a given food and $1 \mathrm{~kg}$ as the maximum value of the lower limit of $z_{r}$ (Table 4).

The choice of the crops and months to be cultivated is connected to the net profit at the end of the production of this crop, that is, in Table 4 we observed that crop 3 and 4 are the least profitable during the year, being only viable their production in months 4 and 10, respectively. That is, in these months these crops have a higher net profit when compared to other crops, which are the result of an increase in the value of the sale or the decrease of the expenses for the production. Thus, we can observe in the mathematical model that we have several crop options, in this case 5; we chose the one with higher net profit at the end of production, having no other 
type of obligatoriness, as for example in the previous result expressed in Table 1, where culture 4 is not cultivated because it is not economically viable for the producer. The animal circulation is shown in Table 5.

Table 4. Area to be cultivated by each of the five crops during each month of the year (ha).

\begin{tabular}{cccccc}
\hline & Crop 1 & Crop 2 & Crop 3 & Crop 4 & Crop 5 \\
\hline Month 1 & 0 & 0 & 0 & 0 & 39.052 \\
Month 2 & 0 & 0 & 0 & 0 & 0.6164 \\
Month 3 & 0 & 30.416 & 0 & 0 & 0 \\
Month 4 & 0 & 0 & 78.669 & 0 & 0 \\
Month 5 & 23.854 & 0 & 0 & 0 & 0 \\
Month 6 & 0 & 0 & 0 & 0 & 0.5668 \\
Month 7 & 0 & 15.016 & 0 & 0 & 0 \\
Month 8 & 138.869 & 0 & 0 & 0 & 0 \\
Month 9 & 17.611 & 0 & 0 & 0 & 0 \\
Month 10 & 0 & 0 & 0 & 14.900 & 0 \\
Month 11 & 87.6952 & 0 & 0 & 0 & 0 \\
Month 12 & 0 & 18.384 & 0 & 0 & 0 \\
\hline
\end{tabular}

Table 5. Transit or animal circulation in each area of the iCLS-NT and month of the year, respectively.

\begin{tabular}{|c|c|c|c|}
\hline & Pasture & Annual Grop & Confinement \\
\hline Month 1 & $\begin{array}{l}\text { Animal } 2 \\
\text { Animal } 4\end{array}$ & $\begin{array}{l}\text { Animal } 1 \\
\text { Animal } 3\end{array}$ & Animal 5 \\
\hline Month 2 & $\begin{array}{l}\text { Animal } 2 \\
\text { Animal } 4\end{array}$ & Animal 3 & $\begin{array}{l}\text { Animal } 1 \\
\text { Animal } 5\end{array}$ \\
\hline Month 3 & $\begin{array}{l}\text { Animal } 2 \\
\text { Animal } 4\end{array}$ & Animal 3 & $\begin{array}{l}\text { Animal } 1 \\
\text { Animal } 5\end{array}$ \\
\hline Month 4 & & $\begin{array}{l}\text { Animal } 1 \\
\text { Animal } 3\end{array}$ & $\begin{array}{l}\text { Animal } 2 \\
\text { Animal } 4 \\
\text { Animal } 5\end{array}$ \\
\hline Month 5 & Animal 4 & $\begin{array}{l}\text { Animal } 1 \\
\text { Animal } 3 \\
\text { Animal } 5\end{array}$ & Animal 2 \\
\hline Month 6 & $\begin{array}{l}\text { Animal } 2 \\
\text { Animal } 4\end{array}$ & $\begin{array}{l}\text { Animal } 3 \\
\text { Animal } 5\end{array}$ & Animal 1 \\
\hline Month 7 & Animal 4 & $\begin{array}{l}\text { Animal } 1 \\
\text { Animal } 3\end{array}$ & $\begin{array}{l}\text { Animal } 2 \\
\text { Animal } 5\end{array}$ \\
\hline Month 8 & Animal 2 & $\begin{array}{l}\text { Animal } 1 \\
\text { Animal } 3\end{array}$ & $\begin{array}{l}\text { Animal } 4 \\
\text { Animal } 5\end{array}$ \\
\hline Month 9 & Animal 4 & $\begin{array}{l}\text { Animal } 3 \\
\text { Animal } 5\end{array}$ & $\begin{array}{l}\text { Animal } 1 \\
\text { Animal } 2\end{array}$ \\
\hline Month 10 & Animal 2 & $\begin{array}{l}\text { Animal } 1 \\
\text { Animal } 3\end{array}$ & $\begin{array}{l}\text { Animal } 4 \\
\text { Animal } 5\end{array}$ \\
\hline Month 11 & Animal 4 & $\begin{array}{l}\text { Animal } 3 \\
\text { Animal } 5\end{array}$ & $\begin{array}{l}\text { Animal } 1 \\
\text { Animal } 2\end{array}$ \\
\hline Month 12 & Animal 2 & $\begin{array}{l}\text { Animal } 1 \\
\text { Animal } 3\end{array}$ & $\begin{array}{l}\text { Animal } 4 \\
\text { Animal } 5\end{array}$ \\
\hline
\end{tabular}

The corresponding animal feed composed of 5 nutrient types (kg), with a minimum sum, that is, equal to zero, is informed by the vector:

\begin{tabular}{ccccc}
\hline Type 1 & Type 2 & Type 3 & Type 4 & Type 5 \\
\hline 9.9270 & 0.2423 & 0.9474 & 0.4753 & 0.4503 \\
\hline
\end{tabular}




\section{Conclusions}

We presented an integrated system of livestock farming (iCLS) on no-tillage called iCLSNT, representing a type of agricultural structure composed of three areas of activity: annual crop, pasture and animal confinement (composition of food, feed and/or pasture, dry matter, crude protein, etc.). We mathematically matched through a mixed integer programming model (MIXP) the activities allowed to be carried out from each area of the iCLS-NT, as well as the transit or animal mobility between the three areas of the system, maximizing agricultural production and weight gain of each animal of the herd considered, and minimizing the feeding and permanence costs of each animal in certain areas of the iCLS-NT. Numerical tests were performed using randomly-generated data, using the MATLAB platform and the results obtained show the validity of MIXP.

\section{Acknowledgments}

The authors are grateful to the anonymous reviewers for critically reviewing the manuscript.

\section{References}

Carvalho M.A.C., Soratto R.P., Athayde M.L.F., Arf O. \& Sá M.E. (2004) Produtividade do milho em sucessão a adubos verdes no sistema de semeadura direta e convencional. Pesquisa Agropecuária Brasileira, 39(1): 47-53. DOI: 10.1590/S0100-204X2004000100007

Delgado A.R.S., Ventura S.D. \& Rodrigues P.C.P. (2016) Otimização da receita líquida com produção agrícola por área irrigada limitada. Pesquisa Operacional para o Desenvolvimento, 8(2): 92-108.

Ferreira J.M.L., Mauricio R.M. \& Madureira A.P. (2010) Oportunidades e desafios na Integração Lavoura-Pecuária-Floresta. Informe Agropecuário, 31(257): 112-120.

Lorenzi H. (2000) Manual de identificação e de controle de plantas daninhas: plantio direto e convencional. Nova Odessa: Instituto Plantarum. 339 p.

Oliveira J.S., Ferreira R.P., Cruz C.D., Pereira A.V., Botrel M.A., von Pinho R.G., Rodrigues J.A.S., Lopes F.C.F. \& Miranda J.E.C. (2002) Adaptabilidade e Estabilidade em Cultivares de Sorgo. Revista Brasileira de Zootecnia, 31(2): 883-889. DOI: 10.1590/S1516-35982002000400011

Pires J.A.A., Rosa W.J., Eboli I.P., Albernaz W.M., Pinto Júnior E.S. \& Mendes M.A. (2010) Programa Estadual de Integração Lavoura-Pecuária-Floresta. Informe Agropecuário, 31(257): 122-127.

Sá M.A.C. \& Santos Junior J.D.G. (2005) Compactação do solo: consequências para o desenvolvimento vegetal. Planaltina: Embrapa-Cerrados. 26 p. 